\title{
THE IMAGE OF THE ARSENITES IN THE CORRESPONDENCE OF ATHANASIUS I, THE PATRIARCH OF CONSTANTINOPLE
}

\author{
Mikhail A. Vishnyak \\ Moscow Theological Academy, Sergiev Posad, Russian Federation
}

\begin{abstract}
The correspondence of the Patriarch of Constantinople Athanasius I (1289-1293, 1303-1309) is one of the most original sources on the Arsenite schism (1265-1310). It largely supplements and corrects our knowledge of the complex problem of the Arsenite schism. The author tries to recreate the whole image of the Arsenites and the Arsenite schism as it is represented in the correspondence of the patriarch Athanasius, to compare it with the data of other sources, and to detect the main features and tendencies of the letters of the patriarch describing the schism.

The patriarch convinces the flock that the Arsenites are schismatics, completely alien to the Church. He does not recognize the Arsenites as true "zealots", comparing them with the ancient schism of Katharoi (Novatians), who mistakenly considered themselves to be pure. He charges the Arsenites with dogmatic, canonical and moral faults, which aims to debunk the Arsenites as advocates of the principles of "akribeia". The patriarch emphasizes the spiritual causes of the schism - sins and vices, showing in this respect a great similarity with Metropolitan Theoleptos of Philadelphia. Despite a strict position, the patriarch tries to return the schismatics to the Church.

Key words: Patriarch Athanasius I of Constantinople, Byzantine literature, Arsenites, schism, metropolite Theoleptos of Philadelphia.

Citation. Vishnyak M.A. The Image of the Arsenites in the Correspondence of Athanasius I, the Patriarch of Constantinople. Vestnik Volgogradskogo gosudarstvennogo universiteta. Seriya 4, Istoriya. Regionovedenie. Mezhdunarodnye otnosheniya [Science Journal of Volgograd State University. History. Area Studies. International Relations], 2017, vol. 22, no. 5, pp. 16-26 (in Russian). DOI: https://doi.org/10.15688/jvolsu4.2017.5.2
\end{abstract}

\section{ОБРАЗ АРСЕНИТОВ В ЭПИСТОЛЯРНОМ НАСЛЕДИИ ПАТРИАРХА АФАНАСИЯ І КОНСТАНТИНОПОЛЬСКОГО}

\author{
Михаил Андреевич Вишняк \\ Московская духовная академия, г. Сергиев Посад, Российская Федерация
}

\begin{abstract}
Аннотация. В ряду весьма скудных источников, касающихся арсенитского раскола (1265-1310 гг.), письма Константинопольского патриарха Афанасия I (1289-1293; 1303-1309) являются уникальным источником, во многом дополняющим и корректирующим взгляд на сложную проблему арсенитского раскола. В настоящей статье предпринята попытка воссоздания целостного образа арсенитов и арсенитского раскола в том виде, в каком он представлен в письменном наследии патриарха, его сопоставление с данными других источников и выявление основных особенностей и тенденций писем патриарха в описании раскола.

Патриарх убеждает паству в том, что арсениты суть раскольники, полностью чуждые Церкви. Он не признает арсенитов истинными «зилотами» (ревнителями), сравнивая их с древним расколом кафаров (новатиан), ошибочно считавших себя чистыми. Он выдвигает против арсенитов догматические, канонические 参 и нравственные обвинения, что имеет целью развенчать арсенитов как поборников принципов «акривии». Патриарх подчеркивает духовные причины раскола - грехи и пороки, являя в этом отношении большое сходство с митрополитом Феолиптом Филадельфийским. Несмотря на строгую позицию, патриарх старает() ся вернуть раскольников в Церковь.
\end{abstract}


Ключевые слова: патриарх Афанасий I Константинопольский, византийская литература, арсениты, раскол, митрополит Феолипт Филадельфийский.

Цитирование. Вишняк М. А. Образ арсенитов в эпистолярном наследии патриарха Афанасия I Константинопольского // Вестник Волгоградского государственного университета. Серия 4, История. Регионоведение. Международные отношения. - 2017. - Т. 22, № 5. - С. 16-26. - DOI: https://doi.org/10.15688/jvolsu4.2017.5.2

Арсенитский раскол является одним из самых сложных феноменов церковной и политической жизни Византии палеологовского периода. Наше знание о нем ограничено довольно скудными источниками, содержащими фрагментарную и противоречивую информацию. Среди этих источников особое место занимают письма Константинопольского патриарха Афанасия I (1289-1293; 1303-1309) ${ }^{1}$, оба патриаршества которого проходили на фоне этой схизмы.

Изучение письменного наследия патриарха Афанасия наталкивается на ряд трудностей; в первую очередь на тот факт, что большая часть его наследия остается до сих пор неизданной. Кроме того, вызывает сложность авторский стиль патриарха, который затрудняет понимание многих мест в его переписке [4, c. $254 ; 41$, p. vi].

Степень изученности арсенитской схизмы в целом следует признать низкой. Из немногих трудов, ей посвященных, следует выделить, прежде всего, объемную монографию Ивана Егоровича Троицкого (1832-1901) «Арсений, патриарх Никейский и Константинопольский, и арсениты» [9]. С 30-х гг. ХХ в., с изданием новых источников, начали появляться значимые научные труды, среди которых следует упомянуть исследования Иоанниса Сикутриса [39], Анастасии Кондоянопулу [24], Париса Гунаридиса [16], статьи Виталиана Лорана [25; 26], Николая Дмитриевича Барабанова [1; 2], Альбера Файе [21], о. Александра Пржегорлинского [5; 6] и других исследователей $[14 ; 37 ; 38 ; 43]$. Ценными комментариями сопровождаются издания соответствующих источников, в частности издания, осуществленные Робертом Синкевичем [11], Панайотисом Николопулосом [30; $31 ; 32]$ и др. Тема арсенитов раскрыта довольно полно в монографии о. Александра Пржегорлинского, посвященной Феолипту Филадельфийскому [7].

Тема отношений патриарха Афанасия с арсенитами так или иначе затрагивается во всех посвященных ему работах, однако не в удовлетворительной степени. Исключениями являются книга американского византиниста Джона Лоуренса Буджамры, в которой арсенитскому вопросу посвящена отдельная глава [13], а также статьи Элис-Мэри Толбот [40] и о. Александра Пржегорлинского [8].

Источники по арсенитской схизме принято разбивать на 3 группы.

I. Исторические источники. В этой группе наибольшую важность представляет хроника Георгия Пахимера [22], подробный и объективный источник, охватывающий период с 1260 по 1308 год. Источниками по ранней стадии раскола являются хроники Георгия Акрополита [3; 23] и Феодора Скутариота [12], противоположные в своих тенденциях: первый является апологетом Михаила VIII, второй - последователем патриарха Арсения. Хроника Никифора Григоры [29] для периода до 1308 г. зависит от Пахимера [20, р. 147], однако является ценным источником по заключительной стадии раскола (1308-1310 гг.). Остальные исторические источники не являются самостоятельными и зависят от вышеперечисленных.

II. Проарсенитские источники. К этой группе относят: Завещание патриарха Арсения [35, р. 947-958]; анонимное Слово о патриархе Арсении [31, б. 449-461]; письмо Макария Писидия Мануилу Диссипату, митрополиту Фессалоникийскому [19, б. 89-94]; письмо монаха Каллиста тому же Мануилу Диссипату [39, t. 3, б. 17-26]; «Слово в защиту отделившихся», приписываемое иеромонаху Иакинфу [32, б. 260-280].

III. Антиарсенитские источники: трактат монаха Мефодия «О схизме...» [35, 140.781805] и его же письмо патриарху Григорию II [18, p. 518-527]; трактат митрополита Ефесского Иоанна Хилы [17, р. 340-413]; две проповеди митрополита Феолипта Филадельфийского [15, б. 305-345; 10$]$.

Задача выделения в рамках корреспонденции патриарха Афанасия писем, связанных с арсенитами, оказывается нетривиальной. С полной несомненностью к ним следует от- 


\section{ВИЗАНТИЙСКОЕ ПРАВОСЛАВИЕ}

нести все письма, в которых говорится о «кси-

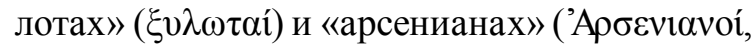
среди изданных писем только в Ер. 69.51). Арсенитов также касается большая часть писем, в которых речь идет о расколе ( $б і ́ \sigma \mu \alpha)$

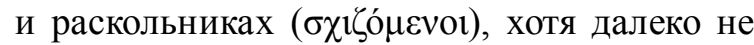
все: патриарх Афанасий употребляет это слово равным образом и в отношении епископов и монахов, прекративших церковное общение лично с ним (см. Еp. 16.1-4; cp. Еp. 69.83-87 и 141-150). Определенную трудность представляют письма, где нет прямых указаний, позволяющих с уверенностью заключить, что имеются в виду именно арсениты или связанные с ними обстоятельства. К ним можно отнести Еp. 34, Ep. 82, Ep. 90, Ep. 105, Ep. 109.

\section{Ep. 19}

Это клятвенное письмо некоего диакона Филиппа Сиропула [36, № 27220], который обвинялся в симпатиях к арсенитам, объявляющее, что впредь он пребудет верным Православной Церкви и отрекается от всех связей с арсенитами (Ер. 19.7-13). Личность диакона Филиппа подробнее неизвестна, и датировать письмо не представляется возможным. Издатель Э.-М. Толбот полагает, что оно было включено в сборник писем Афанасия I, так как, вероятно, было составлено самим патриархом и представлено диакону на подпись, а затем отправлено императору [41, p. 325].

Употребляемый в этом и многих других

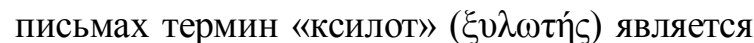
собственным изобретением патриарха Афанасия. Этот остроумный каламбур составлен из

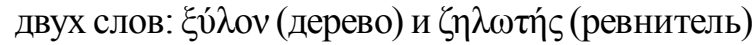
и призван, по-видимому, указывать на непробиваемое упорство арсенитов. Толбот приво-

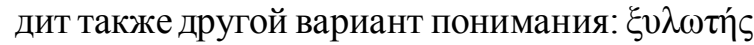

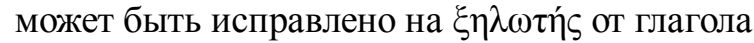
$\xi \eta \lambda \omega ́ v \omega$ (димотическая форма от $\dot{\varepsilon} \xi \eta \lambda \tilde{\omega})-$ «раздирать, рвать, расщеплять», что может быть связано с раскольническим характером арсенитов [41, p. 326]. По мнению Н.Д. Барабанова, «называя арсенитов «ксилотами» (что означает «деревяшки, дубинки»), Афанасий I как бы хотел показать, что, облачаясь в священнические одеяния, эти «дубинки» являются теми орудиями убийства, которыми уничтожается стадо Христово» [2, с. 59-60].
Однако можно предполагать, что главной целью патриарха Афанасия было не позволить арсенитам закрепить за собой звание

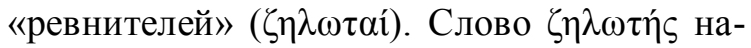
стойчиво и последовательно употреблялось арсенитами к самим себе, в том числе в официальных документах (например, Гро́ $\mu \mu \alpha \tau \tilde{\omega} v$

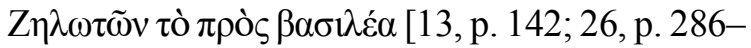
287]). В недавно обнаруженном письме Афанасия I императору из рукописи Alexandrinus gr. 288 (911) патриарх пишет о зилотах: «Прозываясь благовидным именем, они зорко следят, чтобы всуе слыть ревнителями» [34, p. 450]. В другом письме, адресованном клиру Святой Софии, патриарх упоминает различные категории «презирающих Церковь» и среди них «охваченных недугом чистых ( $\tau \tilde{\omega} v$ $\kappa \alpha \theta \alpha \rho \tilde{\omega} v)$ - по прозванию, но не по произволению» [33, б. 307-308]. Издатель видит в этих словах возможное указание на арсенитов. Кафары («чистые», новатиане) - ригористический христианский раскол III-VII веков. Их главная претензия к официальной иерархии состояла в том, что они считали, что нельзя принимать в церковное общение тех, кто совершил смертный грех [42, p. 1497]. Если перевести эти претензии на канонический язык, то «чистые» отказывались от возможности применения икономии к падшим и считали это достаточным основанием для отделения от церковной иерархии. Возможно, патриарх намекает именно на это обстоятельство арсенитского раскола.

В первом предложении отречения диакона предается анафеме тот, кто «исповедует какой-либо догмат или убеждение не так, как исповедует... Церковь» (Ер. 19.7-9).

Вероятно, эта анафема призвана продемонстрировать, что Церковь и ее иерархия ни в чем не отступает от православного вероучения и, следовательно, все претензии арсенитов в этом отношении беспочвенны. Действительно, несмотря на отказ Андроника II в 1282 г. от Лионской унии, вероучительный вопрос никогда не считался для арсенитов решенным. О его значении в их глазах говорит тот факт, что отвержение всех еретических учений и утверждение учения святых отцов и Православной Церкви было вторым условием заключенного в 1310 г. мира между арсенитами и Церковью [26, p. 260; 13, p. 147]. 
В проповедях митрополита Феолипта Филадельфийского имеются свидетельства о выдвигавшихся арсенитами догматических претензиях [15, б. 342.548-550]. О. Александр Пржегорлинский полагает, что речь может идти о неопределенной позиции иерархии в отношении спорного томоса патриарха Григория Кипрского о «вечном явлении» Духа Святого либо о других претензиях вероучительного характера [7, с. 104-108].

Однако вполне возможно, что формулировка письма носит не только защитительный, но и обвинительный характер. В процессе формирования раскола у арсенитов развилась довольно специфическая экклезиология, суть которой состояла в учении о «невидимой Церкви», имеющей непорочную иерархию, членов которой знает только Бог [43, p. 158]. Очевидно, такие воззрения выходили за рамки канонических вопросов, так как ниспровергали не только иерархический принцип в Церкви, но и саму ее сакраментальную природу [13, p. 141; 26, p. 270]. Они вполне могли считаться ересью в глазах церковных иерархов; в частности, Феолипт Филадельфийский сравнивал арсенитов, отвергавших совершаемую в официальной Церкви Евхаристию, с теми, кто учит о Христе как о простом человеке $[15, \sigma .327 .200$ 201]. Такие обвинения вполне понятны, поскольку в православном богословии сакраментология, экклезиология и христология тесно связаны, и потому грань между расколом и ересью является лишь условной.

Следующее важное выражение письма -

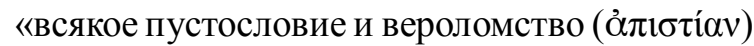
ксилотов против Церкви и против царства» (Ер. 19.9-11). В свете политической экклезиологии Афанасия, представляющей империю как «Новый Израиль» [13, p. 62-70], верность Церкви и верность царству предстают как непременно взаимосвязанные.

\section{Ep. 34}

Второе важное письмо, полностью посвященное теме раскола, адресовано Марии Армянской, супруге императора Михаила IX (Ер. 34). Рита-Мария, сестра Хетума II, царя Киликийской Армении (1289-1305), 16 января 1296 г. вышла замуж за Михаила Палеолога, сына и соправителя Андроника II [36,
№ 21394]. Дата свадьбы определяет terminus post quem составления письма. В тексте упоминается о желании царицы Марии примирить с Церковью неких отпавших людей. Не вполне ясно, о ком именно идет речь: об армянахантихалкидонитах или об арсенитах? Сложность понимания усугубляется лакуной в рукописи в том самом месте, где ожидалось бы конкретное указание: «Да усмотрит твоя царственность... к Кому ты приводишь $* * *_{\text {» }}$ (Ер. 34.16-17). А.П. Каждан полагает, что в восклицании: «как они могут быть верными царям, даже если в своем коварстве изображают себя такими?» (Ер. 34.24-25) патриарх Афанасий «имеет в виду, скорее всего, не подданных империи (арсенитов), а ее возможных, хотя и ненадежных союзников» [4, с. 253]. Однако, на наш взгляд, эта фраза как раз свидетельствует о том, что речь идет об арсенитах: ведь именно их нелояльность (несмотря на формальное подданство) всегда была проблемой для Палеологов. Поэтому большинство исследователей относят это письмо к арсенитам, которых также естественнее понимать под «отсекшими себя от Церкви» (Еp. 34.23-24).

Хваля Марию за усердие о церковном мире, патриарх пишет ей ряд важных предостережений и наблюдений, раскрывающих его взгляд на раскол (Ер. 34.18-30).

Причиной раскола в глазах патриарха оказывается внутреннее отступление от Бога самого раскольника (Ер. 34.22-23). Страсть, любопрение, упрямство, нераскаянность - вот, согласно Афанасию, глубинные причины раскола (ср. Ер. 6.7-8). К ним же, в сущности, сводят раскол Иоанн Хила [17, p. 358], Григоpa [29, I, p. 261.13-14] и митрополит Феолипт [15, б. 310.113-118]. Взгляд последнего с позиций аскетической психологии представляется особенно близким взглядам патриарха Афанасия [7, с. 109-110].

Вторая часть письма - уникальный пример изложения патриархом Афанасием своей экклезиологии: «Древо жизни - Церковь Христова; как ветвь, отсеченная от здорового дерева, понемногу увядает, засыхает и делается пищей огня (ср. Ин. 15:6), так и здесь. И вот подтверждение: многие после домостроительства воплощения Христа и Бога моего отсекли себя от живоносного древа, то есть 


\section{ВИЗАНТИЙСКОЕ ПРАВОСЛАВИЕ}

от Церкви, или ересью, или расколом. И древо жизни, Церковь, напаиваемая и просвещаемая Христом и Спасителем моим, цветет; а отступившие от нее погибли, как добровольно удалившие себя от Бога» (Ер. 34.31-38). Древо жизни, насажденное посреди рая (Быт. 2:9), - символ бессмертия, как и христианская Церковь, подающая бессмертие. Схожий образ используется патриархом в энциклике, специально разъясняющей проблему «ксилотов» (Reg. 1738) [41, p. 343].

Подобные образы часто использовались в церковной литературе, и эпоха патриарха Афанасия не была исключением [7, с. 98-100]. В своем обширном письме императору (Еp. 69) против церковных нестроений, датируемом между июнем 1303 и 1305 г. [41, p. 382], патриарх повествует о видении «одному из раскольников», в котором ему явился висящий на Кресте Спаситель с растерзанной на пять частей плотью, и один из этих разрывов - из-за арсенитов (Ер. 69.51-52). Возможно, в понимании большинства эти распространенные образы были не более чем поражающими воображение метафорами, но для патриарха Афанасия они были, очевидно, отражением созерцаемой им мистической реальности $[6$, с. 58].

\section{Reg. № 1737, 1738}

Патриарх Афанасий придавал достаточно большое значение канонической стороне

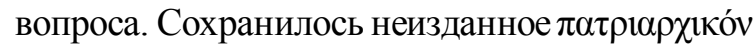
$\gamma \rho \alpha ́ \mu \mu \alpha$ к сановникам и всему верному народу о «ксилотах» (Reg. 1737) с прилагаемым к нему обширным каноническим и патристическим комментарием (Reg. 1738) (без датировки). В последнем патриарх Афанасий показывает заблуждение арсенитов на основании ряда свидетельств святых отцов и правил Вселенских и Поместных соборов. Он доказывает, что раскольники неправы не признавая патриархов, управлявших Церковью после Арсения, и особенно ставит им на вид то, что они не соблюдают подписанных ими актов собора в Атрамитие (1284 г.). Кроме того, патриарх выдвигает против них обвинения в том, что они принимают в общение с собой разбойников, прелюбодеев, лжесвидетелей и всех, кто готов заплатить (Reg. 1738), что они нарушают монашеские обеты и правила, живя в роскоши и обходя дома вдов и богатых, которые предоставляют деньги и помощь раскольникам, тогда как верные терпят нужду (Reg. 1737; cp.: Reg. 1762). Это - волки в овчарне (ср.: Reg. 1744), скрывающие от простого народа под монашеской одеждой свои пороки (Reg. 1737); они нагло разыгрывают из себя духовных отцов (Reg. 1762). Подобные же обвинения звучат из уст митрополита Феолипта [15, б. 307-308.51-62].

Судя по данным других источников, эти обвинения патриарха, возможно, с некоторым преувеличением, соответствуют действительности [16, б. 174-175]. Но в письмах патриарха можно найти и совсем неожиданные подробности: у арсенитов большую роль играли женщины, и монахи принимали постриг и причастие из их рук (Reg. 1605 и Reg. 1737). B Reg. 1605 также говорится о присвоении себе священнических функций всяким, кто ни пожелает. По сути, патриарх обвиняет арсенитов в создании нового (альтернативного общецерковному) предания, то есть образа жизни, богослужения и быта [16, б. 174].

Эти факты позволяют говорить также о том, что арсениты не были последовательны в своем принципе следования акривии. Поэтому следует скорректировать взгляд на проблему арсенитского раскола, согласно которому борьба между арсенитами и церковной иерархией была борьбой за господство принципов акривии или икономии в практике церковной жизни. Во всяком случае следует говорить не об акривии и икономии как таковых, а о принципах и тенденциях их понимания и применения [16, б. 198-199].

\section{Ep. 81}

Следующее важное письмо, касающееся арсенитов - письмо патриарха Афанасия по поводу выступления Иоанна Дримия [36, № 5830]. Согласно последней, наиболее аргументированной датировке, предложенной А. Файе, выступление следует датировать периодом весны - лета 1305 г. [21, p. 235]. Это послание сравнительно хорошо изучено, и нет необходимости разбирать его подробно, поскольку оно касается по преимуществу личности Дримия; однако следует заметить, что 
предложенная Файе датировка (весна - лето 1305, а не зима 1305/06 г., как считалось ранее) требует пересмотра сделанных ранее заключений об этом выступлении, в том числе об участии в нем арсенитов. В частности, возможна новая трактовка изгнания арсенитов из столичного монастыря Мозель и других мест столицы зимой 1305/06 г. [21, p. 240].

Когда заговор был раскрыт, потребовалось участие патриарха, поскольку Дримий выдавал себя за священника. Патриарх направил императору пространное послание (Ep. 81), в котором он с синодом отлучает и извергает из сана Дримия (с оговоркой «если, конечно, он когда-то удостоился его [священства]») и его сообщника из Мир Ликийских.

Из текста можно заключить, что сам Дримий не принадлежал к числу арсенитов. Предположение Толбот, что сообщником Дримия из Мир Ликийских был сочувствовавший арсенитам митрополит Мир Ликийских Лука [41, p. 406-407], едва ли может быть принято $[38, \sigma .468-470]$. Заговорщики, однако, пользовались поддержкой арсенитов: «[Дримий] попытался возмутить и погрузить в глубину ве-

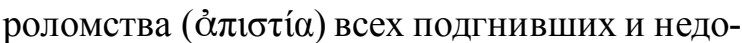

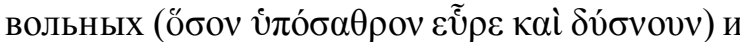
царем, и Богом из народа, и прежде и более всего - из ксилотов» (Ер. 81.85-87). О час-

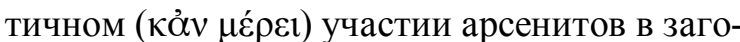
воре сообщает также Пахимер [22, vol. IV, p. 653.19-22].

В глазах патриарха арсениты суть какие-то испорченные, подгнившие члены общества, всегда готовые на любое антицерковное и антигосударственное деяние. В другом письме патриарх жалуется на то, что главе арсенитов Иакинфу было позволено собрать вокруг себя все отребие общества [22, vol. III, p. 189.11-15].

Исходя из скудных данных источников, исследователи делали разные предположения об участии арсенитов в заговоре [2, с. $58-59 ; 7$, с. $110-111 ; 16, \sigma .182-183 ; 24$, б. 222; 38, б. 480-481; 39, t. 2, б. 292]. Исходя непосредственно из текста письма, следует сказать, что арсенитская тема в нем не педалируется, как этого можно было бы ожидать. «Ксилоты» упоминаются в нем однажды (Ep. 81.87). Патриарх находит весьма суровые эпитеты для организаторов за- говора, которые названы: «Этот Иоанн Дримий, козлоолень ( $\tau \rho \gamma \varepsilon \lambda \alpha \dot{\alpha} \varphi \omega)$, и его приспешник Сарданапал и их единомышленники» (Еp. 81.146-148), - но ввиду того, что степень участия арсенитов в заговоре неясна, нет возможности уверенно относить все эти эпитеты к арсенитам. Ни обвинение, ни требование наказать злодеев не касается их напрямую. Ясно, что и церковное отлучение (Ер. 81.142-145) не могло иметь никакого воздействия на арсенитов.

\section{Ep. 109}

Это письмо посвящено возвращению раскольников в Церковь, хотя нет возможности уверенно отнести его к арсенитам. Из текста письма явствует лишь то, что патриарха Афанасия по-настоящему волновал вопрос не о формальном возвращении в Церковь раскольников (чего было бы достаточно для василевса), а об их действительном внутреннем изменении (Ер. 109.7-17).

\section{Ep. 115}

Важно выяснить также реакцию патриарха на мир с арсенитами, выраженную в Ер. 115. Толбот вслед за Лораном датирует письмо периодом между вторым отречением патриарха Афанасия I (сентябрь 1309) и избранием в патриархи Нифонта (май 1310), повидимому, исходя из того, что Нифонт в письме не упоминается. В конце письма Афанасий порицает епископов за то, что патриарх Иосиф «стал жертвой неистовства раскольников» (Ер. 115.132-133). Скорее всего, речь идет об изъятии имени Иосифа из диптихов, которое было одним из главных требований арсенитов во все время их противостояния, но было удовлетворено лишь после заключения мира с ними 14 сентября 1310 г. [28, № 2003]. В таком случае письмо должно быть написано после этой даты.

Судя по выраженной мысли (Ер. 115.130 134), главным принципом, с которого патриарх не хотел сходить, была каноническая законность Иосифа и всех следовавших за ним патриархов, а Церковь в его понимании не должна принимать правила от раскольников, констатируя тем самым их правоту. 


\section{ВИЗАНТИЙСКОЕ ПРАВОСЛАВИЕ}

В уже упомянутой рукописи Alexandrinus gr. 288 (911), датируемой издателем М. Патедакисом периодом осень 1310 - 1313 г., мнение Афанасия о мире высказано более мягко $[34$, p. 450]. Патриарх упоминает также о своих попытках привлечь арсенитов к миру; напротив того, арсениты убеждали его соединиться с ними и признать «свое заблуждение» [34, p. 450].

Упоминания об арсенитах встречаются во многих других местах писем патриарха Афанасия. Палитра патриарха для них не отличается разнообразием красок. Они - хранители «суетного и ложного» (Ер. 115.80-81). Отступничество арсенитов от Церкви равносильно отступничеству от Христа, что больше всякого греха (Reg. 1777). Этим они влекут гнев Божий на мир, к напастям которого, помимо прочих, прибавились и дела арсенитов; из-за них-то мир наказывается (Reg. 1737). Задача императора - «исхищать израилитян от осязаемой тьмы раскольников» (Ер. 90.1213). Они действуют изнутри Церкви, бесстыдно раскалывая еe (Reg. 1692), не колеблясь удалять верующих из ее лона (Reg. 1627). Анафема всем, кто пытается отделить верующих и священников от Церкви Христовой; верные должны убегать от неистовства раскольников, которые чужды Богу (Reg. 1776). Но молитва патриарха о том, чтобы всемогущий Бог обратил их в верных православных (Reg. 1762). Все зло - последствие греха, в частности, того, что совершают ксилоты, оставаясь отделенными от Церкви. Писание запрещает принимать их в своем доме, даже приветствовать (Reg. 1777).

Таким образом, в письмах патриарха Афанасия I арсенитский раскол предстает в исключительно негативном свете. Автор видит в раскольниках сознательных врагов как Церкви, так и государства. Патриарх не уделяет внимания династической стороне вопроса, переводя конфликт исключительно на каноническую почву, на которой арсениты, в его глазах, непременно терпят поражение. Причиной раскола являются грехи и страсти раскольников, и патриарх указывает пастве на проявления этих пороков в среде арсенитов, равно как и на тщетность их претензий на каноническую и догматическую непогрешимость и на само имя «ревнителей». Господствует биб- лейский мотив отделения и противопоставления (Церковь («Новый Израиль») и раскольники, паства Христова и «волки»). Примирение арсенитов с Церковью возможно только при условии их отказа от своих «заблуждений» и порождающих раскол страстей, то есть покаяния.

Все вышесказанное относится к официальной стороне деятельности патриарха, то есть к его посланиям и письмам, которые имеют своей целью пресечение распространения раскола. Но, как было показано, за этой внешне жесткой и непримиримой позицией патриарха стояли усилия по возвращению арсенитов в Церковь.

Образ схизмы, воссоздаваемый с опорой на письменное наследие патриарха Афанасия, носит субъективные черты и не может претендовать на всесторонность и полноту. Он обусловлен, во-первых, положением предстоятеля, ответственного за единство Церкви, вовторых, самим жанром и целью посланий, призванных уберечь паству, и, наконец, категоричным характером самого патриарха. И вместе с тем этот образ имеет ряд общих черт с другими свидетельствами современников, прежде всего - с содержащимися в наследии митрополита Феолипта Филадельфийского [8, c. 102-104]. Это позволяет говорить о внутренней идейной связи, об определенной общей линии, выразителями и представителями которой были эти два иерарха. Их писания отражают, несомненно, важную грань сложного феномена арсенитской схизмы и, в сопоставлении с другими источниками, представляют собой уникальные свидетельства современников, без которых наше знание об этом феномене церковной истории Византии не может быть полным.

\section{ПРИМЕЧАНИЕ}

${ }^{1}$ В данной статье мы будем пользоваться в основном изданием Э.-М. Толбот [41], а также конспектом неизданных писем Афанасия, выполненным В. Лораном [27]. Цитируя или ссылаясь в дальнейшем на письма в издании Толбот, мы будем использовать аббревиатуру Ер. и указывать номер письма в издании и номер строки. Для регестов Лорана будем использовать аббревиатуру Reg. и порядковый номер в регестах. 


\section{СПИСОК СОКРАЩЕНИЙ} ститута.

ЗРВИ - Зборник радова Византолошког ин-

$R E B$ - Revue des études byzantines.

$C F H B$ - Corpus Fontium Historiae Byzantinae.

$C S H B$ - Corpus Scriptorum Historiae Byzantinae.

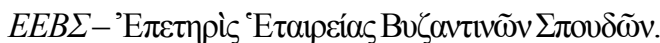

\section{СПИСОК ЛИТЕРАТУРЫ}

1. Барабанов, Н. Д. Борьба внугри византийской церкви на рубеже XIII-XIV вв. / Н. Д. Барабанов // Античная древность и средние века. - 1981. - [Вып. 18]: Античный и средневековый город. - С. 141-156.

2. Барабанов, Н. Д. О характере выступления Иоанна Дримия в начале XIV в. / Н. Д. Барабанов // Античная древность и средние века. - 1980. [Вып. 17]: Античные традиции и византийские реалии. - С. 53-60.

3. Георгий Акрополит. История / Георгий Акрополит ; пер., вступ. ст., комм. и прил. П. И. Жаворонкова ; отв. ред. Г.Г. Литаврин. - СПб. : Алетейя, 2005. -415 с.

4. Каждан, А. П. Рецензия на: The Correspondence of Athanasius I, Patriarch of Constantinople. Letters to theEmperor Andronicus II, Members of the Imperial Family, and officials. An edition, translation and commentary by A.-M. M. Talbot. Washington, 1975 / А. П. Каждан // Византийский Временник. - 1978. - Т. 39 (64). C. 252-255.

5. Пржегорлинский, А. А. Антиарсенитскиетрактаты св. Феолипта Филадельфийского / А. А. Пржегорлинский // Мир Православия : сб. ст. -2004. - Вып. 5.C. $124-134$.

6. Пржегорлинский, А. А. Арсенитская схизма в изображении св. Феолипта Филадельфийского и личность Феолипта в свете его противостояния арсенитам / А. А. Пржегорлинский // Мир Православия : сб. ст. Волгоград : Изд-во ВолГУ, 2002. - Вып. 4. - С. 51-76.

7. Пржегорлинский, А. (священник). Византийская Церковь на рубеже XIII-XIV вв. Деятельность и наследие св. Феолипта, митрополита Филадельфийского / священник А. Пржегорлинский. СПб. : Алетейя, 2011.-240 с.

8. Пржегорлинский, А. А. (священник). Святые Афанасий I Константинопольский и Феолипт Филадельфийский: неприязнь или беспристрастное единомыслие? / священник А. А. Пржегорлинский // Мир Православия : сб. ст. - Волгоград : Изд-во ВолГУ, 2008. - Вып. 7. - С. 99-106.

9. Троицкий, И. Е. Арсений, патриарх Никейский и Константинопольский, и арсениты / И. Е. Троицкий. - СПб. : Тип. Деп. уделов, 1873. - 534 с.
10. Феолипт Филадельфийский, святитель. Антиарсенитские трактаты / святитель Феолипт Филадельфийский ; пер. с др.-греч., примеч. А. А. Пржегорлинского // Мир Православия : сб. ст. - 2004. Вып. 5. - С. 134-163.

11. A Critical Edition of the Anti-Arsenite Discourses of Theoleptos of Philadelphia / ed. by R. E. Sinkewicz // Medieval Studies. - 1988. - V. 50.P. 46-95.

12. Bibliotheca graeca medii aevi / ed. by K. H. Sathas. - Venetia; Paris : Maisonneuveet cie, 1894. Vol. 7. $-680 \mathrm{p}$.

13. Boojamra, J. Church Reform in the late Byzantine Empire: A study of the patriarchate of Athanasius of Constantinople, 1289-1293, 1303-1309 / J. Boojamra. Thessaloniki : Patriarchal Institute for Patristic Studies,

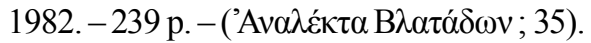

14. Grégoire, H. Le schisme Arséniate et Nicéphore Calliste Xanthopoulos / H. Grégoire // Byzantion. - 1929-1930. - T. 5. - P. 758-765.

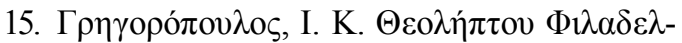

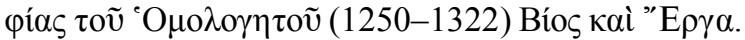

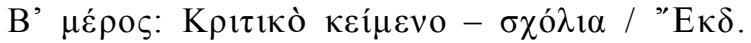

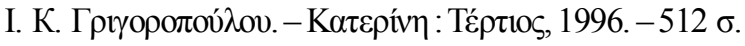

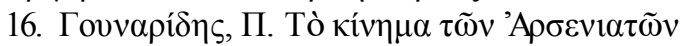

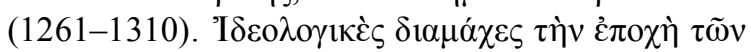

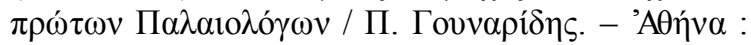

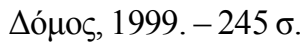

17. Documents inédits d'ecclésiologie byzantine / éd. J. Darrouzès. - Paris : Institut français d'études byzantines, 1966. - 442 p. - (Archives de l'Orient Chrétien ; 10).

18. Dossier grec de l'union de Lyon (1273-1274) / éd. V. Laurent, J. Darrouzès. - Paris : Institut français d'études byzantines, 1976. - 611 p. - (Archives de l'Orient Chrétien ; 16).

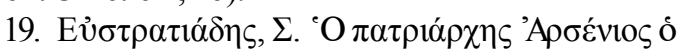

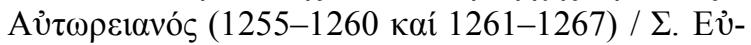

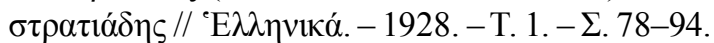

20. Failler, A. La première démission du patriarche Athanase (1293) d'après les documents / A. Failler // REB. - 1992. - T. 50. - P. 137-162.

21. Failler, A. Le complot antidynastique de Jean Drimys / A. Failler // REB. - 1996. - T. 54. - P. 235-244.

22. Georges Pachymérès. Relations historiques.Vol. I / Georges Pachymérès ; éd. A. Failler. - Paris : Société d'édition «Les Belles Lettres», 1984. - xxxvi, 325 p. ; Vol. II. - Paris : Soc. d'éd. «Les Belles Lettres», 1984. - P. 328-667; Vol. III. Paris : Inst. fr. d'études byzantines, 1999. - xxiii, 305 p. ; Vol. IV. - Paris : Inst. fr. d'études byzantines, 1999. P. 310-727; Vol. V-Paris : Inst. fr. d'études byzantines, 2000. - xvii, 373 p. - (CFHB ; 24/1,2,3,4,5).

23. Georgii Acropolitae opera. Vol. $1 /$ rec. A. Heisenberg; ed. by P. Wirth. - Stuttgart : Teubner, 1978. $-366 \mathrm{p}$. 


\section{ВИЗАНТИЙСКОЕ ПРАВОСЛАВИЕ}

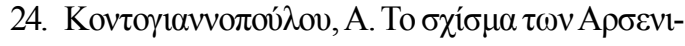

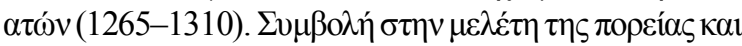

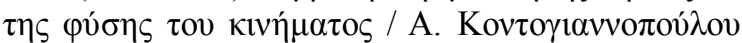

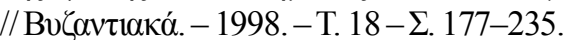

25. Laurent, V. Les crises religieuses à Byzance. Le schisme antiarsénite du métropolite de Philadelphie Théolepte († c. 1324) / V. Laurent // REB. - 1960. T. 18. - P. 45-54.

26. Laurent, V. Les grandes crises religieuses à Byzance : la fin du schisme arseìnite / V. Laurent // Bulletin de la Section Historique [Academie Roumaine]. - 1945.-26.2. - P. 225-313.

27. Les regestes des actes du Patriarcat de Constantinople. Vol. I: Les actes des Patriarches. Fasc. IV: Les regestes de 1208 a 1309 / éd. V. Laurent. - Paris : Inst. fr. d'études byzantines, 1971. $-634 \mathrm{p}$.

28. Les regestes des actes du Patriarcat de Constantinople. Vol. I: Les actes des Patriarches. Fasc. V: Les regestes de 1310 a 1376 / éd. J. Darrouzès. Paris : Inst. fr. d'études byzantines, 1977. - 601 p.

29. Nicephori Gregorae Byzantina historia. Vol. 1 / ed. by L. Schopen. - Bonn : imp. ed. Weberi, 1829. 568 p. - (CSHB; 19.I).

30. Niко

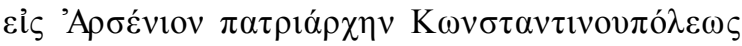

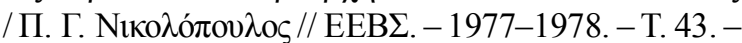
ऽ. 365-383.

31. Nıко $\lambda$ ó

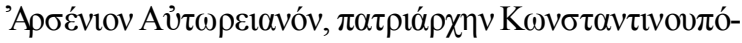

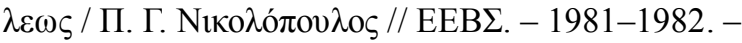
T. 45. $-\Sigma .406-461$.

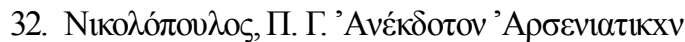

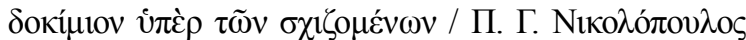
// EEB $\Sigma . ~-1990-1991 .-T .48 .-\Sigma .164-280$.

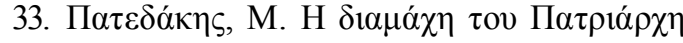
A $\theta \alpha v \alpha \sigma i ́ o v ~ A^{\prime}(1289-1293,1303-1309) \mu \varepsilon \tau o v \kappa \lambda \eta ́ \rho o$

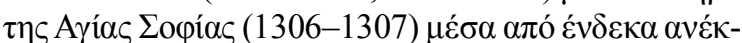

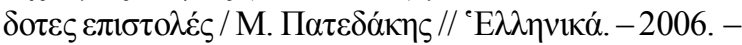
T. 56. - ऽ. 279-319.

34. Patedakis, M. The Testament of the Patriarch Athanasios I of Constantinople (1289-93, 1303-09) / M. Patedakis // Byzantine Religious Culture: Studies in Honor of Alice-Mary Talbot / ed. by D. SullivanElizabeth Fisher-Str. Papaioannou. - Leiden ; Boston : Brill, 2012.- P. 439-463.

35. Patrologia cursus completus. Series graeca. Vol. 140. Nicetae Choniatae opera omnia [et al.] / ed. by J.-P. Migne. - Paris : apud Garnier fratres, 1881.$1620 \mathrm{p}$.

36. Prosopographisches Lexikon der Palaiologenzeit /hrsg. E. Trapp, R. Walther, H.-V. Beyer [et al.]. - Electronic data. - Wien : Verl. d. Österr. Akad. d. Wiss., 2001. 1 electronic disk (CD-ROM). - Title from screen.

37. Salaville, S. Deux documents inedits sur les dissensions religieuses byzantines entre 1275 et 1310 / S. Salaville // REB. - 1947 - T. 5. - P. 116-136.

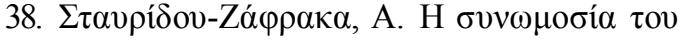

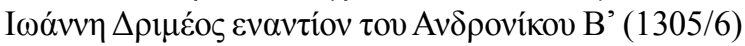

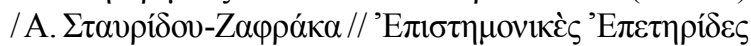

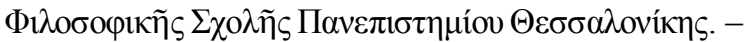
1983. - T. 21. $-\Sigma .461-487$.

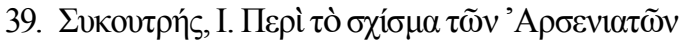

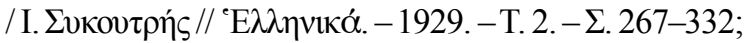
1930. -T. 3. $-\Sigma .15-44 ; 1932 .-T .5 .-\Sigma .107-126$.

40. Talbot,A.-M. M. ThePatriarch Athanasius(1289 1293; 1303-1309) and the Church / A.-M. M. Talbot // Dumbarton Oaks Papers. - 1973. - Vol. 27. -P. 11-28.

41. The correspondence of Athanasius I, patriarch of Constantinople: letters to the emperor Andronicus II, members of the imperial family, and officials / Ed. and trans. A.-M.M. Talbot. - Washington, D.C. : Dumbarton Oaks Center for Byzantine Studies, 1975. - lii + 467 p.(CFHB; 3).

42. The Oxford Dictionary of Byzantium. - T. 3.N. Y. : Oxford Univ. Press, 1991.-1475-2232 p.

43. Tudorie, I.-A. Le schisme arsenite (1265-1310): entre akribeia et oikonomia / I.-A. Tudorie // ЗРВИ. 2011. - XLVIII. - P. 133-175.

\section{REFERENCES}

1. Barabanov N.D. Borba vnutri vizantiyskoy tserkvi na rubezhe XIII-XIV vv. [The Struggle within the Byzantine Church at the Turn of the $13^{\text {th }}-14^{\text {th }}$ Centuries]. Antichnaya drevnost i srednie veka, 1981, vol. 18, pp. 141-156.

2. Barabanov N.D. O kharaktere vystupleniya Ioanna Drimiya v nachale XIV v. [On the Character of the Riot of Ioannes Drimys at the Beginning of the $14^{\text {th }}$ Century]. Antichnaya drevnost i srednie veka, 1980, vol. 17, pp. 53-60.

3. Georgiy Akropolit. Istoriya [Georges Acropolites. History]. Saint Petersburg, Aletheia Publ., 2005. 415 p.

4. Kazhdan A.P. Retsenziya na: The Correspondence of Athanasius I, Patriarch of Constantinople. Letters to the Emperor Andronicus II, Members of the Imperial Family, and officials. An edition, translation and commentary by A.-M. M. Talbot. Washington, 1975 [Book Review: The Correspondence of Athanasius I, Patriarch of Constantinople. Letters to the Emperor Andronicus II, Members of the Imperial Family, and officials. An edition, translation and commentary by A.-M. M. Talbot]. Vizantiyskiy vremennik [Byzantina Xronika], 1978, vol. 39 (64), pp. 252-255.

5. Przhegorlinskiy A.A. Antiarsenitskie traktaty sv. Feolipta Filadelfiyskogo [The Anti-Arsenite Discourses of St. Theoleptos of Philadelphia]. Mir Pravoslaviya: Sbornik statey [Orthodox World. Collected Articles]. Volgograd, Izd-vo VolGU, 2004, iss. 5, pp. 124-134. 
6. Przhegorlinskiy A.A. Arsenitskaya skhizma v izobrazhenii sv. Feolipta Filadelfiyskogo i lichnost Feolipta v svete ego protivostoyaniya arsenitam [The Reflection of the Arsenite schism by St. Theoleptos of Philadelphia and His Personality in the Light of His Opposition to the Arsenites]. Mir Pravoslaviya: Sbornik statey [Orthodox World. Collected Articles]. Volgograd, Izd-vo VolGU, 2002, pp. 51-76.

7. Przhegorlinskiy A., priest. Vizantiyskaya Tserkov na rubezhe XIII-XIV vv. Deyatelnost $i$ nasledie sv. Feolipta, mitropolita Filadelfiyskogo [The Byzantine Church at the Turn of the $13^{\text {th }}-$ $14^{\text {th }}$ Centuries. The Activities and Heritage of St. Theoleptos, Metropolitan of Philadelphia]. Saint Petersburg, Aletheia Publ., 2011. 240 p.

8. Przhegorlinskiy A.A., priest. Svyatye Afanasiy I Konstantinopolskiy i Feolipt Filadelfiyskiy: nepriyazn ili bespristrastnoe edinomyslie? [Saint Athanasius I of Constantinople and Theoleptos of Philadelphia: Disfavor or Impartial Like-Mindedness?]. Mir Pravoslaviya: Sbornik statey [Orthodox World. Collected Articles]. Volgograd, 2008, iss. 7, pp. 99-106.

9. Troitskiy I.E. Arseniy, patriarkh Nikeyskiy $i$ Konstantinopolskiy, $i$ arsenity [Arsenius, Patriarch of Nikaea and Constantinople, and the Arsenites]. Saint Petersburg, Tip. Dep. udelov, 1873. 534 p.

10. Theoleptos of Philadelphia, Holy Hierarch. Antiarsenitskie traktaty [The Anti-Arsenite Tractates]. Mir Pravoslaviya: Sbornik statey [Orthodox World. Collected Articles]. Volgograd, Izd-vo VolGU, 2004, iss. 5, pp. 134-163.

11. Sinkewicz R.E., ed. ACritical Edition of the AntiArsenite Discourses of Theoleptos of Philadelphia. Medieval Studies, 1988, vol. 50, pp. 46-95.

12. Sathas K.H., ed. Bibliotheca graeca medii aevi. Venetia; Paris, Maisonneuve et cie, 1894, vol. 7. $680 \mathrm{p}$.

13. Boojamra J. Church Reform in the late Byzantine Empire: A study of the patriarchate of Athanasius of Constantinople, 1289-1293, 13031309. Thessaloniki, Patriarchal Institute for Patristic Studies, 1982. 239 p. ('Av $\alpha \lambda \varepsilon ́ \kappa \tau \alpha$ B $\lambda \alpha \tau \alpha ́ \delta \omega v ; 35)$.

14. Grégoire H. Le schisme Arséniate et Nicéphore Calliste Xanthopoulos. Byzantion, 1929-1930, vol. 5, pp. 758-765.

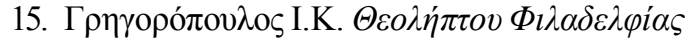

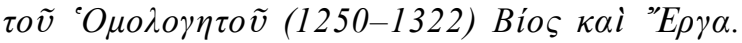

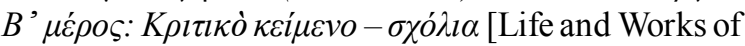
Theoleptos of Philadelphia the Confessor (1250-1322).

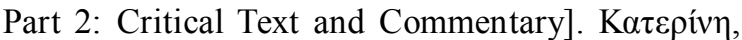

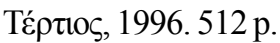

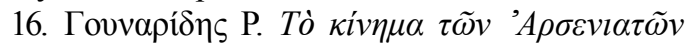

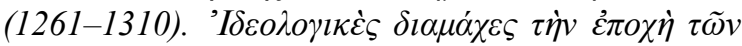

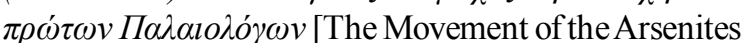
(1261-1310). Ideological Conflicts at the Age of the Early

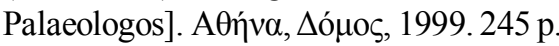

17. Darrouzès J., ed. Documents inédits d'ecclésiologie byzantine. Paris, Institut français d'études byzantines, 1966. 442 p. (Archives de l'Orient Chrétien, 10).

18. Laurent V., Darrouzès J., eds. Dossier grec de l'union de Lyon (1273-1274). Paris, Inst. fr. d'études byzantines, 1976. 611 p. (Archives de l'Orient Chrétien; 16).

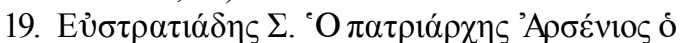

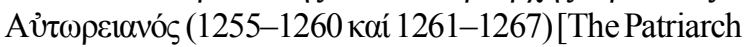
Arsenius Autorianus (1255-1260 and 1261-1267)].

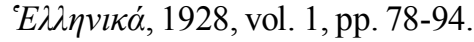

20. Failler A. La première démission du patriarche Athanase (1293) d'après les documents. REB, 1992, vol. 50, pp. 137-162.

21. Failler A. Le complot antidynastique de Jean Drimys. REB, 1996, vol. 54, pp. 235-244.

22. Failler A., ed. Georges Pachymérès. Relations historiques. Vol. I. Paris, Société d'édition "Les Belles Lettres", 1984. xxxvi, 325 p.; Vol. II. Paris, Soc. d'éd. "Les Belles Lettres", 1984, pp. 328-667; Vol. III. Paris, Inst. fr. d'études byzantines, 1999. xxiii, 305 p.; Vol. IV. Paris, Inst. fr. d'études byzantines, 1999, pp. 310-727; Vol. V. Paris, Inst. fr. d'études byzantines, 2000. xvii, 373 p. (CFHB; 24/1,2,3,4,5).

23. Georgii Acropolitae opera. Vol. 1. Stuttgart, Teubner, 1978. $366 \mathrm{p}$.

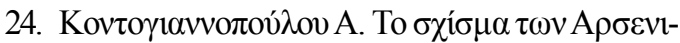

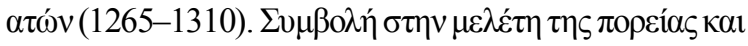

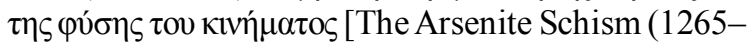
1310). A Contribution to the Study of the Course and the Nature of the Movement]. Byzantiaka, 1998, vol. 18, pp. 177-235.

25. Laurent V. Les crises religieuses à Byzance. Le schisme antiarsénite du métropolite de Philadelphie Théolepte († c. 1324). REB, 1960, vol. 18, pp. 45-54.

26. Laurent V. Les grandes crises religieuses à Byzance: la fin du schisme arseìnite. Bulletin de la Section Historique [Academie Roumaine], 1945, vol. 26.2, pp. 225-313.

27. Laurent V., ed. Les regestes des actes $d u$ Patriarcat de Constantinople. Vol. I: Les actes des Patriarches. Fasc. IV: Les regestes de 1208 a 1309. Paris, Inst. fr. d'études byzantines, 1971. $634 \mathrm{p}$.

28. Darrouzès J., ed. Les regestes des actes $d u$ Patriarcat de Constantinople. Vol. I: Les actes des Patriarches. Fasc. V: Les regestes de 1310 a 1376. Paris, Inst. fr. d'études byzantines, 1977. $601 \mathrm{p}$.

29. Schopen L., ed. Nicephori Gregorae Byzantina historia. Vol. 1. Bonn, imp. ed. Weberi, 1829. 568 p. (CSHB; 19.I).

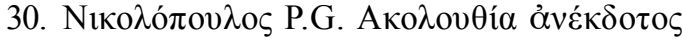

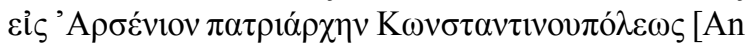
Un published Akolouthia to Arsenius, the Patriarch of Constantinople]. EEBS, 1977-1978, vol. 43, pp. 365-383. 


\section{ВИЗАНТИЙСКОЕ ПРАВОСЛАВИЕ}

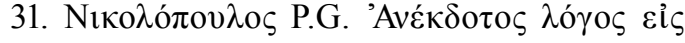

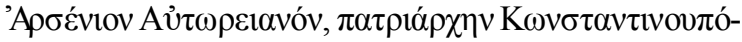
$\lambda \varepsilon \omega \varsigma$ [An Unpublished Logos to Arsenius Autorianus, the Patriarch of Constantinople]. EEBS, 1981-1982, vol. 45, pp. 406-461.

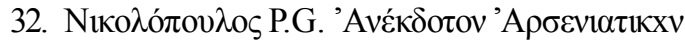

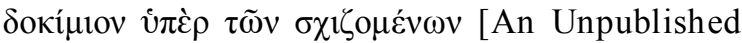
Document in Defence of the Schismatics]. EEBS, 1990 1991, vol. 48, pp. 164-280.

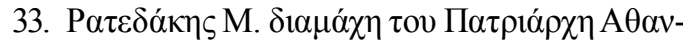

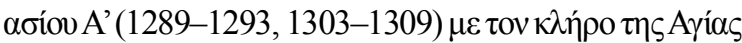

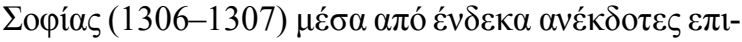
$\sigma \tau \mathrm{\alpha} \dot{\varepsilon} \varsigma$ [The Conflict of the Patriarch Athanasius I (1289-1293, 1303-1309) with the Clergy of St. Sophia

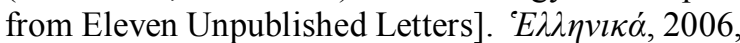
vol. 56, pp. 279-319.

34. Patedakis M. The Testament of the Patriarch Athanasios I of Constantinople (1289-93, 1303-09). Sullivan D., Fisher E., Papaioannou Str., eds. Byzantine Religious Culture: Studies in Honor of Alice-Mary Talbot. Leiden; Boston, Brill, 2012, pp. 439-463.

35. Migne J.-P., ed. Patrologia cursus completus. Series graeca. Vol. 140. Nicetae Choniatae opera omnia. Paris, apud Garnier fratres, 1881.1620 p.

36. Trapp E., Walther R., Beyer H.-V., eds. (et al.) Prosopographisches Lexikon der Palaiologenzeit.
Wien, Verl. d. Österr. Akad. d. Wiss., 2001. 1 electronic $\operatorname{disk}(\mathrm{CD}-\mathrm{ROM})$.

37. Salaville S. Deux documents inedits sur les dissensions religieuses byzantines entre 1275 et 1310 . $R E B, 1947$, vol. 5, pp. 116-136.

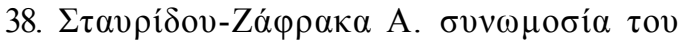

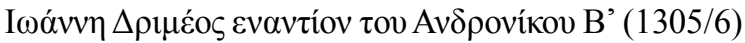
[The Conspiracy of Ioannes Drimys against

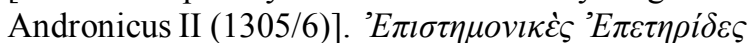

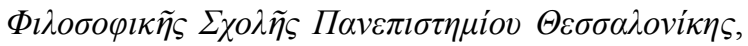
1983, vol. 21, pp. 461-487.

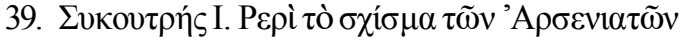

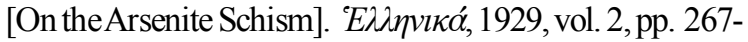
332; 1930, vol. 3, pp. 15-44; 1932, vol. 5, pp. 107-126.

40. Talbot A.-M.M. The Patriarch Athanasius (1289-1293; 1303-1309) and the Church. Dumbarton Oaks Papers, 1973, vol. 27, pp. 11-28.

41. Talbot A.-M.M., ed. The correspondence of Athanasius I patriarch of Constantinople: letters to the emperor Andronicus II, members of the imperial family, and officials. Washington, D.C., Dumbarton Oaks Center for Byzantine Studies, 1975, lii + 467 p. (CFHB; 3).

42. The Oxford Dictionary of Byzantium. T. 3. New York, Oxford Univ. Press, 1991, pp. 1475-2232.

43. Tudorie I.-A. Le schisme arsenite (1265-1310): entre akribeia et oikonomia. ZRVI, 2011, 48, pp. 133-175.

\section{Information about the Author}

Mikhail A. Vishnyak, Master of Theology, Postgraduate Student, Moscow Theological Academy, Holy Trinity-St., Sergius Lavra, 141300 Sergiev Posad, Russian Federation, gweharall@gmail.com, http:/ /orcid.org/0000-0003-3354-9553

\section{Информация об авторе}

Михаил Андреевич Вишняк, магистр богословия, аспирант Московской духовной академии, Троице-Сергиева Лавра, 141300 г. Сергиев Посад, Российская Федерация, gweharall@gmail.com, http://orcid.org/0000-0003-3354-9553 